\title{
CHARTING THE WRONG COURSE: THE DOCTRINE OF LEGITIMATE EXPECTATIONS IN INVESTMENT TREATY LAW
}

\author{
TREVOR ZEYL*
}

The need to redefine the scope of the doctrine of legitimate expectations in investment treaty law is apparent. This article examines the domestic sources of the doctrine of legitimate expectations in order to evaluate whether investment treaty tribunals are justified in interpreting the doctrine of legitimate expectations to include substantive expectations. It concludes that recognizing substantive expectations as a part of the general principles of law is at this point premature and amounts to a misstatement of a general principle of law. There must be due consideration to the notion of deference as found in different domestic jurisdictions, including the doctrines of constraint found in common law.
Le besoin de redéfinir la portée de la doctrine des attentes légitimes en droit conventionnel d'investissement est évident. Cet article examine les sources nationales de la doctrine des attentes légitimes afin d'évaluer si les tribunaux de traités d'investissement ont raison d'interpréter la doctrine des attentes légitimes de manière à inclure des attentes considérables. L'auteur conclut que le fait de reconnaître des attentes considérables dans le cadre des principes généraux de droit est actuellement prématuré et constitue une inexactitude du principe général de droit. Il faut dûment tenir compte de la notion de déférence telle qu'elle existe dans plusieurs juridictions nationales, incluant les doctrines de contrainte que l'on retrouve dans la common law.

\section{TABLE OF CONTENTS}

I. INTRODUCTION:

The Doctrine of Legitimate EXPECtATIONS . . . . . . . . . . . . . . . . . 204

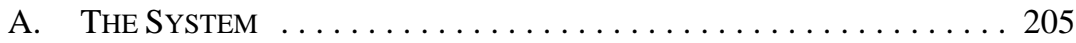

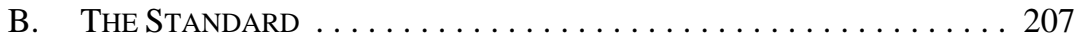

C. The Problem ................................ 208

D. Outline of ARticle . . . . . . . . . . . . . . . . . . . . . . . . . 209

II. SyStEMIC ISSUES IN INVESTMENT TREATY INTERPRETATION $\ldots \ldots \ldots . . .209$

III. DOMESTIC VARIANCE IN THE APPLICATION OF

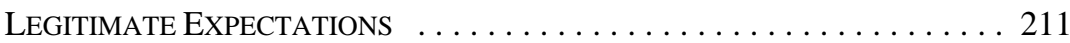

A. UnitED KingDOM . . . . . . . . . . . . . . . . . . . . . . . . . 211

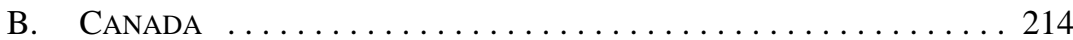

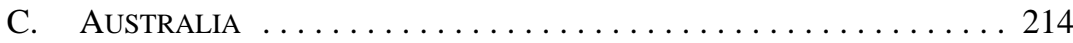

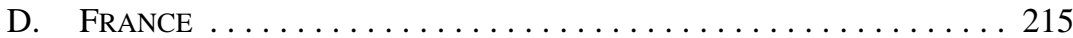

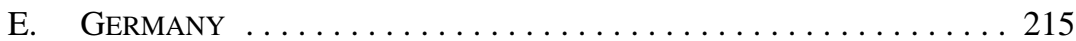

F. EUROPEAN COMMUNITY ...................... 216

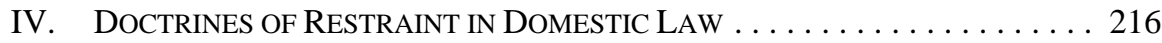

A. Parliamentary or Legislative Supremacy . . . . . . . . 217

B. Ultra Vires Doctrine and the Rule Against Fettering . . . . 217

C. SEPARATION OF PoWERS Doctrine $\ldots \ldots \ldots \ldots \ldots \ldots \ldots \ldots . \ldots \ldots$

D. Some OBSERVATIONS . . .......................... 219

V. SubSTANTIVE LEGITIMATE EXPECTATIONS

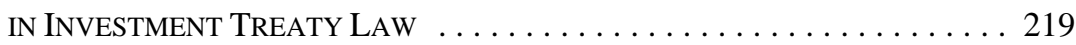

BA (Hons) (WLU), MA (WLU), MSc (LSE), JD (Windsor), LLM (LSE). The author would like to thank Anthea Roberts for her direction as well as Professor Emir Aly Crowne-Mohammed and Professor Maureen Irish for their comments on earlier drafts. 
VI. TOWARDS A NEW DEFINITION $\ldots \ldots \ldots \ldots \ldots \ldots \ldots \ldots \ldots \ldots . \ldots \ldots$

A. Legitimate ExPeCtations: The PREdicAment . . . . . . . . . . . . 224

B. What is the CoMmon Core Content? . . . . . . . . . . . . . 225

C. IMPORTATION OF DOMESTIC DOCTRINES OF RESTRAinT . . . . . . 226

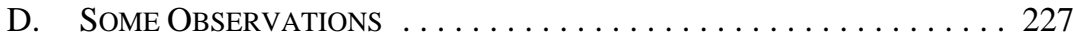

VII. THE WAY FORWARD . . . . . . . . . . . . . . . . . . . . . 228

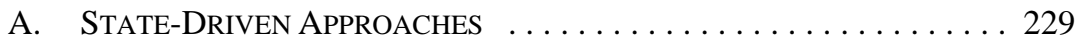

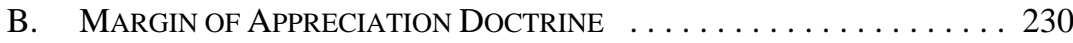

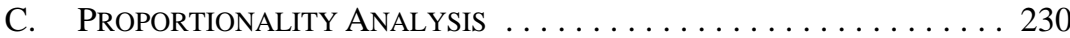

D. DEFERENCE IN INVESTMENT TREATY JURISPRUDENCE $\ldots \ldots \ldots \ldots 231$

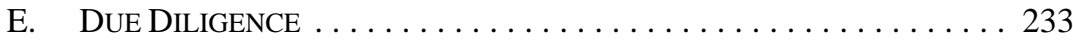

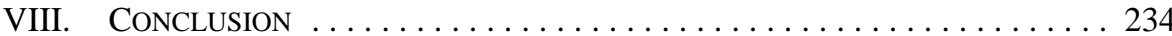

The protection of foreign investments is not the sole aim of the Treaty, but rather a necessary element alongside the overall aim of encouraging foreign investment and extending and intensifying the parties' economic relations. That in turn calls for a balanced approach to the interpretation of the Treaty's substantive provisions for the protection of investments, since an interpretation which exaggerates the protection to be accorded to foreign investments may serve to dissuade host States from admitting foreign investments and so undermine the overall aim of extending and intensifying the parties' mutual economic relations. ${ }^{1}$

\section{INTRODUCTION: \\ THE DOCTRINE OF LEGITIMATE EXPECTATIONS}

The jurisprudence of investment treaty tribunals is shaping the contours of international law. Tribunals, tasked with construing the meaning of investment treaty provisions in congruence with the intentions of the contracting parties and the relevant international legal principles, are creating new bodies of jurisprudence in their awards. More often, the legal reasoning found in these awards is adopted in the decisions of subsequent tribunals, creating a body of law with precedential value. ${ }^{2}$ What happens if this reasoning lacks a sound legal basis, fails to properly consider the contracting parties' intentions, or is based on an inaccurate interpretation of international law? These interpretive failures have the potential to create an investment environment marked by instability and unpredictability, and most significantly, undermine the legitimacy of the investment treaty regime.

Unfortunately, this is the predicament in which the investment treaty regime currently finds itself. The incorporation of the doctrine of legitimate expectations as a general principle of law by investment tribunals is illustrative of this interpretive failure. The doctrine of

Saluka Investments BV (The Netherlands) v The Czech Republic (Partial Award) (Permanent Court of Arbitration, 17 March 2006) at para 300, online: Permanent Court of Arbitration <http://www.pcacpa.org> [Saluka].

See Gabrielle Kaufmann-Kohler, “Arbitral Precedent: Dream, Necessity or Excuse?” (2007) 23:3 Arb Int'l 357 at 361; Anthea Roberts, "Power and Persuasion in Investment Treaty Interpretation: The Dual Role of States” (2010) 104:2 AJIL 179 at 189; Campbell McLachlan, Laurence Shore, and Matthew Weiniger note that: "while no de jure doctrine of precedent exists in investment arbitration, a de facto doctrine has in fact been building for some time.” Campbell McLachlan, Laurence Shore \& Matthew Weiniger, International Investment Arbitration: Substantive Principles (New York: Oxford University Press, 2007) at 18. 
legitimate expectations, a subsidiary component of the fair and equitable treatment standard, ${ }^{3}$ is found in the administrative law of a number of domestic jurisdictions. ${ }^{4}$ The general principles of law are a source of international law derived from article 38.1(c) of the Statute of the International Court of Justice. ${ }^{5}$ Their content is determined by comparing national legal practices and extracting "[s]tandards common to all (or most) national legal systems."” To date, investment tribunals have failed to comprehensively examine the practices of domestic jurisdictions that recognize the doctrine of legitimate expectations when determining the scope of the doctrine. Specifically, tribunals have adopted an approach to the doctrine which recognizes a substantive legitimate expectation. This approach gives tribunals the jurisdiction to review the content of administrative decisions. In contrast, many domestic legal systems consider the doctrine as only providing procedural protection, limiting the review power of courts to the examination of how administrative decisions were adopted. This marks a failure by investment tribunals to consider the reasons why this approach is rejected in so many other jurisdictions.

The growing body of investment jurisprudence that recognizes a substantive legitimate expectation forms what can be considered a misstatement of international law. Moreover, it facilitates a potential crisis of legitimacy for the investment treaty regime since it provides tribunals with a standard of review that is a direct threat to a state's sovereignty. ${ }^{7}$ In order to overcome this threat, tribunals must anchor their conception of the doctrine of legitimate expectations in the "core content" of its domestic application on the broadest scale.

\section{A. THE SYSTEM}

There has been a substantial increase in the number of multilateral and bilateral investment treaties (BITs) concluded between states. Usage of the incorporated arbitration provisions has likewise followed suit. As Benedict Kingsbury and Stephan Schill note:

Investor-State arbitration, particularly under the more than 2,500 bilateral investment treaties (BITs) and several important regional treaties, including NAFTA and the ASEAN investment treaty, is a burgeoning field, with more than 300 investment treaty-based disputes publicly known and many new arbitrations being initiated each year. ${ }^{8}$

Rudolf Dolzer and Christoph Schreuer describe the fair and equitable treatment standard as being "reminiscent of general codes in civil law countries that set forth a number of specific rules and complement these with a general clause of good faith as an overarching principle that fills gaps and informs the understanding of specific clauses.” Rudolf Dolzer \& Christoph Schreuer, Principles of International Investment Law (New York: Oxford University Press, 2008) at 122.

4 Jürgen Schwarze lists the following countries as recognizing the protection of legitimate expectations: Germany 22; the Netherlands 23; Belgium 24; Denmark 25; Greece 26; Italy 27; the United Kingdom 28; Australia 29; New Zealand 30; and a supranational system, being the European Community, 31. Chester Brown, “The Protection of Legitimate Expectations as a 'General Principle of Law': Some Preliminary Thoughts” (2009) 6:1 Transnational Dispute Management 1 at 4, citing Jürgen Schwarze, European Administrative Law, revised 1st ed (London: Sweet \& Maxwell, 2006).

56 June 1945, Can TS 1945 No 7.

6 Martti Koskenniemi, “General Principles: Reflexions on Constructivist Thinking in International Law," in Martti Koskenniemi, ed, Sources of International Law (Burlington: Ashgate, 2000) 359 at 363.

$7 \quad$ Charles N Brower \& Stephan W Schill, "Is Arbitration a Threat or a Boon to the Legitimacy of International Investment Law?” (2009) 9 Chicago J Int'l L 471 at 474.

$8 \quad$ Benedict Kingsbury \& Stephan Schill, "Investor-State Arbitration as Governance: Fair and Equitable Treatment, Proportionality and the Emerging Global Administrative Law,” in Albert Jan van den Berg, ed, 50 Years of the New York Convention, ICAA International Arbitration Conference (Alphen aan den Rijn, Netherlands: Kluwer Law International, 2009) 5 at 7. 
As of 2009, there were 357 known disputes. Also as of 2009, 81 countries had been respondents to investment treaty arbitrations, a disproportionate number coming from developing countries (49) and countries with transitional economies (15). ${ }^{9}$

The mechanics of investment treaty regime are such that foreign investors have direct legal recourse against host governments whose actions have an adverse impact on their investment and amount to a violation of one or more of the various treatment standards found in the investment treaty. ${ }^{10}$ Many of the provisions found in investment treaties are standards found in international law, and thus, tribunals are required to determine their scope and content before determining their applicability. Campbell McLachlan, Lawrence Shore, and Matthew Weiniger summarize the nuanced investment arbitral system:

\footnotetext{
The result is dispute resolution which is arbitration in procedural terms, but which in substance has been said to share more of the characteristics of the direct right of action before human rights courts. The State will always be the respondent, never a claimant. Its conduct vis-à-vis the investor falls to be judged according to general standards imposed by international law and not by reference to any national system of law. ${ }^{11}$
}

In practice, states often find themselves as respondents to claims that directly relate to their governance obligations, such as regulating the environment, financial markets, and tax policy. $^{12}$

When investors are successful and the tribunal finds that the state has violated a standard, the tribunal will award compensatory damages to the investor. As Susan Franck notes, a "typical claim might involve an investor demanding over US\$300 million from a host state." 13 Though only a portion of these claims are successful, the potential financial consequences are enough to leave states feeling apprehensive about their regulatory actions. Furthermore, states have limited recourse against these awards. Tai-Heng Cheng, in comparing investment treaty arbitration to the domestic courts, notes: "Whereas an appellate court may correct a wrongly-decided lower court decision, arbitral awards are not generally subject to appellate review by another arbitral tribunal or even by a national court."

United Nations Conference on Trade and Development (UNCTAD), Latest Developments in InvestorState Dispute Settlement, IIA Issues Note No 1 UN Doc IA/2010/3 (2010) at 2, online: UNCTAD $<$ http://www.unctad.org/en/docs/webdiaeia20103_en.pdf $>$.

Such as national treatment, most-favoured nation treatment, and expropriation provisions. McLachlan, Shore \& Weiniger, supra note 2 at 5 [footnote omitted].

Susan D Franck, “Development and Outcomes of Investment Treaty Arbitration” (2009) 50:2 Harv Int'l LJ 435 at 435.

Ibid.

Tai-Heng Cheng, “Precedent and Control in Investment Treaty Arbitration” (2007) 30:4 Fordham Int'l LJ 1014 at 1024. It should be noted that under the International Centre for Settlement of Investment (ICSID) Convention, awards may only be annulled on limited grounds that do include error or law per se. For awards made under conventions such as United Nations Commission on International Trade Law (UNCITRAL) and the ICSID Additional Facility Rules, judicial review of awards is limited to a narrow set of grounds. 


\section{B. THE STANDARD}

The doctrine of legitimate expectations, said to be the "dominant element" of the fair and equitable treatment standard, ${ }^{15}$ is a creation "borrowed from [domestic] administrative law." 16 As will be examined in Part III, the doctrine of legitimate expectations comes in a variety of forms in the domestic context. The basic test for finding a violation of a legitimate expectation, taken from the tribunal in International Thunderbird Gaming Corp $v$ The United Mexican States, ${ }^{17}$ is an examination of whether the:

Contracting Party's conduct creates reasonable and justifiable expectations on the part of an investor (or investment) to act in reliance on said conduct, such that a failure by the NAFTA [Thunderbird is a NAFTA case, but the test has been widely cited by other tribunals] Party to honour those expectations could cause the investor (or investment) to suffer damages. ${ }^{18}$

In essence, as Søren Schønberg argues: "The legal protection of expectations by administrative law principles is a way of giving expression to the requirements of predictability, formal equality, and constancy inherent in the Rule of Law." " Each domestic jurisdiction carries varying perspectives on how and when the doctrine is to be applied. A more generalized distinction can be drawn, however, between domestic jurisdictions that recognize the doctrine as referring to procedural protections and others that recognize that the doctrine affords protection to both procedural and substantive expectations.$^{20}$ For states that restrict the doctrine of legitimate expectations to procedural protection, a number of common principles/doctrines of judicial review ${ }^{21}$ are set in place to govern the relationship between the judiciary and the discretion given to administrative bodies.

The doctrine of legitimate expectations has made its way to the forefront of investment treaty jurisprudence. The content of the doctrine as recognized by tribunals in investment treaty law is continually evolving, but as Andrew Newcombe and Lluís Paradell note, has been characteristically been employed in three ways:

In its most specific form, legitimate expectations refers to expectations arising from the foreign investor's reliance on specific host state conduct, usually oral or written representations or commitments made by the host state relating to an investment. Reliance typically takes the form of making an initial investment or the expansion of an existing one. Protection of legitimate expectations in this sense is closely related to the principle of estoppel and state responsibility under public international law for unilateral acts. Second, tribunals have referred to legitimate expectations of a stable and predictable legal and administrative framework that meets certain minimum standards, including consistency and transparency in decision-

Saluka, supra note 1 at para 302.

McLachlan, Shore \& Weiniger, supra note 2 at 234; Brown outlines the list of countries that recognize the doctrine as being Germany, the Netherlands, Belgium, Denmark, Greece, Italy, the United Kingdom, Australia, New Zealand, and the European Community. Brown, supra note 4 at 4.

(Arbitral Award) (NAFTA, 26 January 2006), online: University of Victoria <http://ita.law.uvic.ca/ documents/ThunderbirdAward.pdf>.

Ibid at para 147.

Søren J Schønberg, Legitimate Expectations in Administrative Law (New York: Oxford University Press, 2000) at 13-14.

Andrew Newcombe \& Lluís Paradell, Law and Practice of Investment Treaties: Standards of Treatment (Alphen aan den Rijn, Netherlands: Kluwer Law International, 2009) at 280 [footnotes omitted].

Such as legislative supremacy, the rule against fettering, the separation of powers doctrine, and the ultra vires principle. These will be discussed in depth in Part IV, below. 
making. Third, at the most general level, legitimate expectations can be used to refer to the 'expectation that the conduct of the host State subsequent to the investment will be fair and equitable.' This would appear to be simply another way of stating that the investor has a reasonable expectation that the host state will comply with its IIA obligations. ${ }^{22}$

This article will review awards based on the "stable and predictable legal and administrative framework," as it is these awards that provide examples of investment tribunals reviewing the content of administrative decisions.

\section{The Problem}

Prior to its inclusion in investment treaty jurisprudence, the doctrine of legitimate expectations had no real presence in international law. Its incorporation into international law by investment tribunals was recognized through its adoption as a general principle of law. As mentioned, determining the content of legitimate expectations as a general principle requires tribunals to engage in a comparative analysis of domestic jurisdictions in the hope of identifying certain commonalities. So far, tribunals have failed to comprehensively consider what constitutes the common elements of the domestic recognition of the doctrine of legitimate expectations. The jurisprudence of investment tribunals has consistently recognized the doctrine of legitimate expectations to include a substantive expectation, despite the fact that a number of jurisdictions reject this approach. Common law countries such as the United Kingdom, Canada, and Australia, have strong bodies of case law which limit the application of the doctrine to procedural protections. They justify their position by invoking the core principles/doctrines of judicial review including the ultra vires doctrine, the rule against fettering, and the separation of powers doctrine (collectively, "doctrines of restraint”). Investment tribunals have failed, for the most part, to consider the notions of deference found in these doctrines.

Constructing a general principle of law that includes a substantive expectation is problematic. It is problematic for host states who recognize the doctrine of legitimate expectations as limited to providing procedural protection because the host state is subject to review by standards that are unfamiliar to, and unanticipated by, their administrative bodies. Specifically, there is a dissonance between the evaluative methods used by the tribunal in determining whether a violation has occurred and those used by the host state in ensuring its regulatory actions are legal. This creates an unpredictable legal and business environment: the very problem the doctrine of legitimate expectations seeks to address. The fact that recognition of a substantive expectation creates a legal avenue for a tribunal to rule on the legality of a host state's regulatory actions is also problematic. It allows "privately contracted adjudicators to determine the legality of sovereign acts and to award public funds to businesses that sustain loss as a result of government regulation. This undermines basic hallmarks of judicial accountability, openness, and independence."23

22 Supra note 20 at 279-80 [footnotes omitted].

23 Gus Van Harten, Investment Treaty Arbitration and Public Law (New York: Oxford University Press, 2007) at 5. 


\section{OUTLine of ARTicle}

This article examines the domestic sources of the doctrine of legitimate expectations in order to evaluate whether investment treaty tribunals are justified in interpreting the doctrine to include substantive expectations. It concludes that recognizing substantive expectations as part of the general principles of law is at this point premature and amounts to a misstatement of a general principle of law. In Part II, the systemic interpretive challenges presented by the investment treaty law regime are reviewed, paying specific attention to the construction of the general principles of law. Part III examines the variances in the domestic application of the doctrine of legitimate expectations. Part IV identifies the doctrines of restraint that are common to a number of these domestic jurisdictions. Part V expounds upon how the doctrine of legitimate expectations has been recognized in investment treaty law, paying specific attention to the emergence of the requirement that host states maintain a "stable and predictable investment environment." 24 Part VI considers how the investment treaty regime would benefit from the incorporation of the notion of deference as found in the doctrines of restraint. Part VII evaluates the methods of accomplishing this task. This section includes an examination of an emergence of a body of case law that has integrated a "balancing test" when considering legitimate expectations.

\section{SYSTEMIC ISSUES IN INVESTMENT TREATY INTERPRETATION}

Since there is no de jure doctrine of precedent in investment treaty law, tribunals are not obligated to follow previous jurisprudential interpretations and are free to construe the meaning of treaty provisions from their own independent inquiries. The result is a high level of interpretive responsibility borne by the arbitrators. It also contributes to a body of awards that can at times be inconsistent or conflicting. ${ }^{25}$

The duty of the elected tribunal to interpret the investment treaty comes from the consent of the contracting parties. The methodology for completing this task is found in article 31 of the Vienna Convention on the Law of Treaties, which requires tribunals to interpret treaties "with the ordinary meaning to be given to the terms of the treaty in their context and in the light of its object and purpose." ${ }^{26}$ When there is no explicit evidence of the parties intentions, tribunals have the option of looking to "supplementary means of interpretation." 27 The discretionary implications of the phrase "supplementary means of interpretation" are somewhat broad and allow tribunals to use various sources, such as the travaux preparatoires. Moreover, article 42 of the International Centre for Settlement of Investment Disputes (ICSID) Convention, ${ }^{28}$ a source of jurisdiction for many investment treaty

Meg Kinnear, “The Continuing Development of the Fair and Equitable Treatment Standard” in Andrea K Bjorklund, Ian A Laird \& Sergey Ripinsky, eds, Investment Treaty Law: Current Issues III, Remedies in International Investment Law, Emerging Jurisprudence of International Investment Law (London: British Institute of International and Comparative Law, 2008) at 233.

25 See generally Susan D Franck, "The Legitimacy Crisis in Investment Treaty Arbitration: Privatizing Public International Law Through Inconsistent Decisions” (2005) 73:4 Fordham L Rev 1521. 23 May 1969, 1155 UNTS 331, art 31.

Ibid, art 32.

ICSID Convention, Regulations and Rules, April 2006, ICSID/15, online: ICSID <http://icsid.world bank.org/ICSID/StaticFiles/basicdoc/ CRR_English-final.pdf>. 
arbitrations, directs tribunals to "in the absence of express choice, to apply host State law 'and such rules of international law as may be applicable.”,29

Investment treaties often consist of substantive rules that are "based on autonomous treaty law specifically negotiated among the parties" while other parts "restate customary international law that would be applicable even in the absence of a treaty." 30 When dealing with substantive rules that have their origin in international law, investment tribunals employ a variety of sources of international law to determine their content. The fair and equitable treatment standard, a provision included in most investment treaties, is a standard that is found in international customary law and is not a product of domestic law. ${ }^{31}$ It is an abstract standard, with no "consolidated and conventional core meaning." ${ }^{32}$ As Stephan Schill notes:

So far, it is only settled that fair and equitable treatment constitutes a standard that is independent from the national legal order and is not limited to restricting bad faith conduct of host States. Apart from this very minimal concept, however, its exact normative content is contested, hardly substantiated by State practice, and impossible to narrow down by traditional means of interpretive syllogism. ${ }^{33}$

The incorporation of the doctrine of legitimate expectations, a domestic administrative law concept, into the fair and equitable treatment standard, an international legal standard, was accomplished by using general principles of law. As noted in Part I, above, the substance of the general principles of law, although debated, is a derivation of common standards as found in domestic law. ${ }^{34}$ Investment treaty tribunals often use general principles of law to extract "principles applicable to investment contracts"35 and "to inform the content of an existing, but open-textured treaty norm" such as the fair and equitable treatment standard. ${ }^{36}$ McLachlan argues that "the main route through which practice under investment treaties contributes to the development of general international law is through the elucidation of general principles of international law." ${ }^{\text {,7 }}$ Muthucumaraswamy Sornarajah agrees and notes that "general principles have acquired a role in the shaping of rules in the area of foreign investment protection." 38

The problem, however, is that tribunals are contributing to the development of a body international law that is inaccurate, or at least fails to reflect "a common sense in the domestic legal systems." 39 Perhaps this is due to the fact that tribunals are given wide interpretive discretion, yet lack a straightforward directive on how to determine the content

Campbell McLachlan, “Investment Treaties and General International Law” (2008) 57:2 ICLQ 361 at 370 [emphasis omitted].

Rudolf Dolzer, "The Impact of International Investment Treaties on Domestic Administrative Law" (2005) 37 NYUJ Int'l L \& Pol 953 at 957.

Dolzer \& Schreuer, supra note 3 at 123.

Stephan W Schill, The Multilateralization of International Investment Law (New York: Cambridge University Press, 2009) at 263.

Ibid at 263 [footnote omitted].

Brown considers general principles of law "as referring to the existence of general principles which are applicable in domestic legal orders.” Brown, supra note 4 at 3.

M Sornarajah, The International Law on Foreign Investment, 3d ed (New York: Cambridge University Press, 2010) at 86 [Sornarajah, Foreign Investment].

Supra note 29 at 396.

Ibid at 364

Sornarajah, Foreign Investment, supra note 35 at 86.

Ioana Tudor, The Fair and Equitable Treatment Standard in the International Law of Foreign Investment (New York: Oxford University Press, 2008) at 100. 
of the general principles of law. How many domestic legal systems must be examined and how similar the standards must be are examples of methodological questions without consistent answers. It could also be due to the fact that it is in the interest of arbitrators, at least those nominated by investors, to push an arbitral agenda which selects "rules that favour the promotion of investment protection and which are detrimental to the interests of the host state." ${ }^{40}$ It might just be a combination of both.

Despite the difficulties, it is imperative that investment tribunals correctly establish a doctrine of legitimate expectations that reflects, as Ioana Tudor notes, "a common core content to be deducted from the principle despite its different manifestations." ${ }^{41}$ In so doing, tribunals will create jurisprudence that will reflect already held expectations (of host states and investors) and as a corollary, help build more predictability in the investment environment. Failure to reform the doctrine will allow its incorrect version to be legitimated through tribunal repetition.

\section{DOMESTIC VARIANCE IN THE APPLICATION OF LEGITIMATE EXPECTATIONS}

As noted, there are various domestic approaches to the doctrine of legitimate expectations. Its conceptual framework and application varies almost as much as the number of jurisdictions in which it is present. Schønberg identifies these differences within the jurisdictions where pronounced statements on the doctrine have been made that:

while English law relies mostly on procedural protection of expectations, [European Community (EC)] law relies more on substantive principles, and French law on compensation. German, Dutch, and Scandinavian laws resemble EC law; the Commonwealth jurisdictions resemble English law in this area. ${ }^{42}$

For the purposes of this article, the domestic approaches of the UK, Canada, Australia, France, Germany, and the EC will be examined. This review is conducted with a central question in mind: Does the doctrine of legitimate expectations merely affect the procedural rights of the investor, or does it provide for the protection/realization of substantive expectations? It becomes clear from this analysis that there is no general consensus. There is, however, a mutual recognition in the majority of jurisdictions of the importance of giving procedural protections to legitimate expectations (discussed in Part VI, below).

\section{A. UnITED KingdoM}

The doctrine of legitimate expectations was introduced in English law by Lord Denning in Schmidt v Secretary of State for Home Affairs ${ }^{43}$ and used to give "procedural rights to holders of forms of 'new property' — licenses, benefits, and other privileges." ${ }^{44}$ A legitimate

Sornarajah, Foreign Investment, supra note 35 at 86. Brower and Schill identify one of the main criticisms against arbitrators: that arbitrators are likely to be biased towards investors, since appeasing investors will lead to their potential reappointment. Supra note 7 at 489-90.

Supra note 39 at 100.

Schønberg, supra note 19 at 3.

[1968] EWCA Civ 1, [1969] 2 Ch 149.

David Wright, "Rethinking the Doctrine of Legitimate Expectations in Canada” (1997) 35:1 Osgoode Hall LJ 139 at 143 [footnote omitted]. 
expectation, from its inception, was a "procedural legitimate expectation."45 Judicial position has recently shifted, ${ }^{46}$ and recognition of substantive expectations has been adopted in specific circumstances. This position has been tempered by judicial recognition of the deference the judiciary must show the legislature. The law is still changing in this area and has "yet to be finally determined by the courts." 47

$R v$ Ministry of Agriculture Fisheries and Food, ex parte Hamble (Offshore) Fisheries $L t d^{48}$ was the first case to consider broadening the scope of the doctrine's protection "towards the understanding that there might also be 'substantive protection of a substantive legitimate expectation." "49 Justice Sedley laid out the balancing act required:

[I]t is the court's task to recognise the constitutional importance of ministerial freedom to formulate and to reformulate policy; but it is equally the courts duty to protect the interests of those individuals whose expectation of different treatment has a legitimacy which in fairness outtops the policy choice which threatens to frustrate it. ${ }^{50}$

This position was quickly countered in $R v$ Secretary of State for the Home Department and Another, ex parte Hargreaves, ${ }^{51}$ where the Court of Appeal considered whether the expectations of prisoners who were awaiting early release were not fulfilled due to a change of policy. In dismissing the application, Lord Justice Hirst, quoting Lord Diplock, noted:

\begin{abstract}
Administrative policies may change with changing circumstances, including changes in the political complexion of governments. The liberty to make such changes is something that is inherent in our constitutional form of government. When a change in administrative policy takes place and is communicated in a departmental circular ... any reasonable expectations that may have been aroused in them by any previous circular are destroyed. ${ }^{52}$
\end{abstract}

$R v$ North and East Devon Health Authority, ex parte Coughlan, ${ }^{53}$ the next major case dealing with legitimate expectations, made the strongest pronouncement on the procedural/substantive question. In Coughlan, the Court was asked to decide whether a woman who lived under the care of a local health area authority and who was promised that that specific care would continue, had her legitimate expectations breached when this

Peter Leyland \& Gordon Anthony, Textbook on Administrative Law, 6th ed (New York: Oxford University Press, 2009) at 313.

46 JH Jans et al, Europeanisation of Public Law (Groningen: Europa Law Publishing, 2007) at 165. Jans comments on this movement in the UK:

The doctrine of legitimate expectations has long existed in English law, at least in relation to procedural legitimate expectations. Under the doctrine, some legal weight is accorded to policy practices and promises of the administration, though a public authority may depart from such practices and promises, provided it gives adequate reasons for its departure and hears interested parties beforehand. However, until recently — as late as the end of the previous century — it was not recognized that practices and promises could also create substantive legitimate expectations. [Footnote and emphasis omitted.]

47 SH Bailey, Cases, Materials and Commentary on Administrative Law, 4th ed (London: Sweet \& Maxwell, 2005) at 599.

[1995] 2 All ER 714 [Hamble].

Leyland \& Anthony, supra note 45 at 320.

Hamble, supra note 48 at 731.

[1997] 1 WLR 906 [Hargreaves].

Ibid at 919, Lord Justice Hirst citing Hughes v Department of Health and Social Security, [1985] AC 776 at para 788.

[2001] QB 213 (CA) [Coughlan]. 
arrangement was altered. In ruling on the case, the Court set out the requisite circumstances in which a court will review policy changes. They wrote:

\begin{abstract}
Where the Court considers that a lawful promise or practice has induced a legitimate expectation of a benefit which is substantive, not simply procedural, authority now establishes that here too the court will in a proper case decide whether to frustrate the expectation is so unfair that to take a new and different course will amount to an abuse of power. Here, once the legitimacy of the expectation is established, the court will have the task of weighing the requirements of fairness against any overriding interest relied upon for the change of policy. ${ }^{54}$
\end{abstract}

As a result of this decision, the door for an expanded view of the doctrine of legitimate expectations was opened. ${ }^{55}$ It should be noted, however, that Coughlan has been subject to much criticism for raising "fundamental questions about the judicial role on an application for judicial review."56

Though the proposition adopted in Coughlan has been for the most part accepted as good law, the post-Coughlan body of case law has sought to qualify the judgment with statements regarding the deference judicial bodies are required to show the legislature. In $R$ (Bibi) $v$ Newham London Borough Council, ${ }^{57}$ for example, the Court recognized the proposition laid out in Coughlan, but noted while the Court of Appeal accepted that the applicants had a substantive legitimate expectation, it emphasized that

\footnotetext{
it is often not adequate to look at the situation purely from the point of view of the disappointed promisee who comes to the court ... where decisions are informed by social and political value judgments as to priorities of expenditure the court will start with a recognition that such invidious choices are essentially political rather than judicial ... the appropriate body to make that choice in the context of the present case is the authority. ${ }^{58}$
}

In more recent cases, English courts have qualified any discussion of the recognition of a substantive legitimate expectation by asserting the importance of deference. The $R$ (Bhatt Murphy) v Independent Assessor case, ${ }^{59}$ for example, thoroughly considered the position taken in Coughlan. The Court recognized the potential for a substantive legitimate expectation, ${ }^{60}$ if the expectation arose from "a specific undertaking, directed at a particular individual or group, by which the relevant policy's continuance is assured." ${ }^{\prime 1}$ However, the Court qualified these statements by again reiterating the principle of deference. They stated:

Public authorities typically, and central government par excellence, enjoy wide discretions which it is their duty to exercise in the public interest. They have to decide the content and the pace of change. Often they

Ibid at para 57 [emphasis omitted].

This approach has been limited to situations where there has been direct representation made and where the individual has relied on the expectation to their detriment. Martina Künnecke, Tradition and Change in Administrative Law: An Anglo-German Comparison (Heidelberg: Springer Verlag, 2006) at 108. Leyland \& Anthony, supra note 45 at 329.

[2002] 1 WLR 237 [Bibi].

Ibid at paras 35, 64 .

[2008] EWCA Civ 755 [Bhatt Murphy].

Ibid at para 27.

Ibid at para 43. 
must balance different, indeed opposing, interests across a wide spectrum. Generally they must be the masters of procedure as well as substance. ${ }^{62}$

\section{B. CANADA}

The Canadian conception of the doctrine of legitimate expectations reflects its common law roots. Canada has adopted a procedural understanding of the doctrine, but departed from the UK's more recent development recognized in Coughlan. Canadian case law is somewhat uniform in expressing that when legitimate expectations arise they lead to a duty of procedural fairness/due process, not substantive review. ${ }^{63}$ One leading jurist describes the doctrine of legitimate expectations as "a part of the rules of procedural fairness which can govern administrative bodies. Where it is applicable, it can create a right to make representations or to be consulted. It does not fetter the decision following the representations or consultation." "64 The Supreme Court of Canada has been clear on this position on a number of occasions. In the seminal Reference Re Canada Assistance Plan (BC) case, ${ }^{65}$ the Supreme Court overturned a previous ruling by the British Columbia Court of Appeal, which recognized the doctrine as having substantive effects. Justice Sopinka was clear: "There is no support in Canadian or English cases [this decision was pre-Coughlan] for the position that the doctrine of legitimate expectations can create substantive rights." 66 In the Mount Sinai Hospital Center v. Quebec (Minister of Health and Social Services) ${ }^{67}$ decision delivered a decade later, the Supreme Court distanced the Canadian position from that taken by UK Courts in the Coughlan case. Justice Binnie, for the majority, stated: "In Canada ... the courts have taken the view that it is generally the Minister who determines whether the public interest overrides or not” to justify frustrating a substantive legitimate expectation. ${ }^{68}$

\section{Australia}

Australian administrative law has also been skeptical of the adoption of substantive legitimate expectations. The High Court has considered the reasoning of the Coughlan case, but has concluded that adopting a substantive expectation would undermine the deference courts must show the legislature, as well as offend the Australian Constitution. ${ }^{69}$ In Attorney General (NSW) $v$ Quin, ${ }^{70}$ the High Court considered the importance of deference shown to Parliament and found that governments require the ability to "revise policies to guide the exercise of discretionary powers, even if that might cause great unfairness to people affected by the policy." ${ }^{71}$ In Re Minister for Immigration and Multicultural Affairs, ex parte Lam, ${ }^{72}$ the High Court acknowledged that recognizing a substantive legitimate expectations doctrine would "involve large questions as to the relations between the executive and judicial

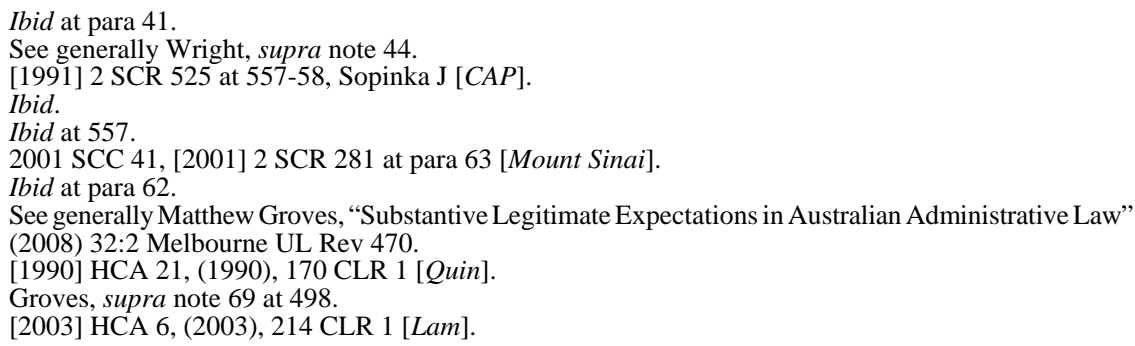


branches of government"73 and ruled "that the jurisdiction vested in the High Court by s 75(v) of the Australian Constitution 'does not exist for the purpose of enabling the judicial branch of government to impose upon the executive branch its ideas of good administration. "'74 Essentially, the Australian Constitution prevents the courts from adopting a substantive legitimate expectation. ${ }^{75}$

\section{FRANCE}

French civil law does not explicitly recognize the doctrine of legitimate expectations. In fact, it has been observed that France has been less than receptive to the principle, perhaps because French law already provides protection for expectations created by administrative decisions. ${ }^{76}$ As Chester Brown notes, this is accomplished "by way of statutory rules, or by reference to other principles such as the right to be heard, the protection of vested rights, and by direct application of the principle of legal certainty." ${ }^{\text {"7 }}$ The protection is not procedural in nature, but addresses the actual reliance on formal and informal administrative representations. ${ }^{78}$ As a matter of practice, Schønberg notes: “The CE [Conseil d'Etat] has generally preferred to compensate loss, caused by reliance on administrative decisions and representations, rather than to impose procedural and substantive limitations on the administrations' discretionary powers." ${ }^{79}$ The Conseil d'Etat has recognized that the doctrine of legitimate expectations is an important principle of EC law, but only applies to French internal legal issues that fall within the scope of EC law. ${ }^{80}$ There are those who feel that this dichotomy (community law versus internal law) will lead to "incoherency and legal uncertainty." ${ }^{\prime 1}$ Time will tell how far the Conseil d'Etat is willing to integrate the doctrine into internal law.

\section{E. GERMANY}

The concept of legitimate expectations is said to have "derived from German law" Germany is still considered to be Europe's clearest and broadest expression of the doctrine. ${ }^{83}$ It contrasts with the abovementioned approaches to the doctrine and instead fully recognizes substantive legitimate expectations. Brown describes the doctrine:

In German law, where the concept is known as Vertrauensschutz, the principle is recognised as a core principle of the Constitution, and applies not only to decisions or representations made by public authorities, but can also be used to defeat legislative measures. ${ }^{84}$

\footnotetext{
Ibid at para 28.

Groves, supra note 69 at 509 [footnote omitted].

Ibid at 511.

Xavier Groussot, General Principles of Community Law (Groningen: Europa Law, 2006) at 428. Brown, supra note 4 at 5.

Groussot argues that "French administrative law provides an extensive protection as to formal decisions through the use of the principles of vested (acquired) rights and non-retroactivity.... The effectiveness of the system of compensation may, in this sense, appear as a palliative to the lack of substantive protection concerning informal representation.” Supra note 76 at 371.

Supra note 19 at 237.

Groussot, supra note 76 at 372.

Ibid at 379.

TC Hartley, The Foundations of European Community Law, 6th ed (New York: Oxford University Press, 2007) at 149.

Brown, supra note 4 at 5.

Ibid.
} 
German courts, when reviewing administrative decisions, weigh competing public interests and the individual protections afforded by the legitimate expectations doctrine. The result of their findings can include the "revocation of unlawful administrative decisions and the withdrawal of lawful administrative decisions." 85 This position is perhaps the most expansive of all jurisdictions when it comes to recognizing substantive legitimate expectations.

\section{F. EUROPEAN COMMUNITY}

Although there is no mention of the doctrine of legitimate expectations in the EC Treaty, it has "been applied [regularly] as an overriding principle" to review the acts of member states. ${ }^{86}$ This recognition includes incorporation of a substantive expectation. The scope for creating legitimate expectations in the EC context is wide, including "by legislation or by administrative decisions,” policy rules or guidelines, and assurances. ${ }^{87}$ This understanding of the principle is derived from its German counterpart. ${ }^{88}$ However, the incongruence between the EC member states and their domestic understanding of the doctrine should not be understated considering that many member states "do not recognize the principle [of legitimate expectations] ... or only to a limited extent" ${ }^{\prime 99}$ and that the principle of legitimate expectations has "not achieved the same status in all [EC] Member States."90

\section{DOCTRINES OF RESTRAINT IN DOMESTIC LAW}

Of the jurisdictions examined in Part III, there are number of shared legal doctrines that speak specifically to the deference judicial bodies must accord administrative bodies/legislative branches. In fact, as Schønberg writes:

\footnotetext{
All developed systems of administrative law include principles of auto-limitation (non-fettering) and legality (ultra vires, légalité).... The justification for these two principles is too well-known.... Briefly, powers are vested in public bodies by legislative provisions, or by constitutional enactment, on the implicit condition that they be exercised lawfully and in the public interest. ${ }^{91}$
}

Common law jurisdictions, most notably the UK, Canada, and Australia, have a strong tradition of limiting the scope of judicial review of administrative action. This tradition relies on the ultra vires doctrine, the rule against fettering, and the separation of powers doctrine - all constitutional principles that define the relationship the judiciary has with administrative discretion. These doctrines are often referred to as the hallmark principles of

Künnecke, supra note 55 at 125 .

Groussot, supra note 76 at 24.

Jans, supra note 46 at 166 [emphasis omitted].

Ibid at 164.

Ibid at 171 .

Brown, supra note 4 at 6, citing Schwarze, supra note 4 at 870.

Supra note 19 at 7 [footnotes and emphasis omitted]. 
"legislative supremacy"92 and have been used to limit the application of the doctrine of legitimate expectations.

\section{A. PARLiAMENTARY OR Legislative SUPREMACY}

Parliamentary/legislative supremacy is a legal principle that holds democratic expression, found in legislative intent, as the supreme voice in determining policy and defining the scope of power of government bodies and the judiciary. It is premised on the idea that elected officials are in a better position to weigh policy decisions against the public interest, rather than the judiciary. ${ }^{93}$ As such, the judiciary should have a limited scope of review of their decisions. Two legal expressions of parliamentary supremacy are the ultra vires doctrine and the rule against fettering.

\section{B. Ultra Vires DOCTRINE AND THE RULE AgAinst FETTERING}

The ultra vires doctrine, described as "the central principle of administrative law,"94 is principally concerned with whether "the limits of parliamentary authorization are respected by administrative authorities." "It is based on the idea that the discretionary flexibility given to administrative bodies reflects the intent of the legislature and as such must be respected by the courts and the administrative bodies themselves. This is because the discretionary freedom given to administrative bodies through elected officials (via legislation) is necessary to enable these bodies to act in the public interest. Limiting this discretion will consequently hurt the public interest. ${ }^{96}$ The rule against fettering, another important principle of administrative law and a common feature of parliamentary democracies, is "itself an application of the ultra vires doctrine."97 It is the rule that prohibits interference with legislative intent. Geneviève Cartier explains how the rule against fettering works in tandem with the ultra vires doctrine in administrative law:

[F]or administrative authorities to act legally they must conform to the statutory authorization and thus preserve their freedom of action. Likewise, courts give effect to the statute in leaving unaffected this freedom to act.... To do otherwise would violate the parliamentary authorization conferred on the decision-making authority ... any attempt to fetter discretion, absent clear statutory indication to the contrary, betrays the

TRS Allan, “Legislative Supremacy and Legislative Intent: A Reply to Professor Craig” (2004) 24:4

Oxford J Leg Stud 563 at 564 [emphasis in original], describes legislative supremacy:

If Parliament's sovereignty is absolute the courts cannot impose constraints on administrative action, developed at common law, except insofar as they serve to support the legislative will. Constraints that inhibit an agency's performance of its statutory functions, perhaps for the protection of individuals' rights or countervailing interests, must at least be consistent with the legislative scheme: a court's intervention that undermined or contradicted the statutory scheme, or underlying general purposes, would flout the legislative sovereignty. Quin, supra note 70 at para 35.

Dawn Oliver, "Is the Ultra Vires Rule the Basis of Judicial Review?” in Christopher Forsyth, ed, Judicial Review and the Constitution (Portland: Hart Publishing, 2000) 3 at 3.

Geneviève Cartier, “A ‘Mullanian’ Approach to the Doctrine of Legitimate Expectations: Real Questions and Promising Answers,” in Grant Huscroft \& Michael Taggart, eds, Inside and Outside Canadian Administrative Law: Essays in Honour of David Mullan (Toronto: University of Toronto Press, 2006) 185 at 193 [emphasis in original].

Daphne Barak-Erez, “The Doctrine of Legitimate Expectations and the Distinction between the Reliance and Expectation Interests” (2005) 11:4 European Public Law 583 at 594.

Cartier, supra note 95 at 194. 
intention of the Parliament because it forces an authority to abandon the free exercise of its powers, contradicting the wishes of the people expressed through the democratic parliamentary process. ${ }^{98}$

As Cartier indicates, both the ultra vires doctrine and the rule against fettering have been employed to maintain the buffer between administrative discretion and the judiciary. In practical terms, they require the judiciary to maintain their distance from decisions held by administrative bodies, unless of course a decision "contravenes the statutory delegation of power, correctly interpreted." ${ }^{99}$ Paul Craig notes the duality implied in the ultra vires principle:

The ultra vires principle is based on the assumption that judicial review is legitimated on the ground that the courts are applying the intent of the legislature... The courts' function is to police the boundaries stipulated by Parliament.... The ultra vires principle thus conceived provided both the basis for judicial intervention and also established its limits.... The courts should not substitute their judgment for that of the agency. ${ }^{100}$

Put another way, the principle places the judiciary in a position where it is charged with monitoring the actions of various governmental bodies to ensure that these bodies operate within their legislated mandate while at the same time respecting the restraints placed on its own judicial functions. This "duality," Nicholas Bamforth maintains, "legitimate[s] the exercise of judicial power within an established constitutional order in which Parliament is sovereign, maintaining a proper balance of power between elected and non-elected institutions." $" 101$

In CAP, Canada's seminal case on legitimate expectations, the Supreme Court of Canada justified the exclusion of a substantive legitimate expectation in Canadian law by recognizing the need to separate legislative discretion from the purview of the courts. The Court overturned a unanimous Court of Appeal decision, which had previously held that provinces could hold a legitimate expectation that their consent was required to enact federal legislation affecting their jurisdiction. In rejecting this argument, Justice Sopinka outlined the Canadian approach to the doctrine against fettering:

Parliamentary government would be paralyzed if the doctrine of legitimate expectations could be applied to prevent the government from introducing legislation in Parliament. Such expectations might be created by statements during an election campaign. The business of government would be stalled while the application of the doctrine and its effect was argued out in the courts. Furthermore, it is fundamental to our system of government that a government is not bound by the undertakings of its predecessor. The doctrine of legitimate expectations would place a fetter on this essential feature of democracy. ${ }^{102}$ 


\section{SeParation OF PoWers Doctrine}

The separation of powers doctrine, a constitutional doctrine recognized in many democratic states, is based on a governance model which normally separates the executive, legislative, and judicial branches of a state. The idea is to remove the respective branches from each other's sphere of influence and prevent a consolidation of power. This doctrine has been employed in domestic judicial discourse with regards to the legitimate expectations doctrine. As mentioned, the High Court of Australia has rejected the substantive legitimate expectations doctrine on the basis that it would run affront to the separation of powers doctrine that is found in the Australian Constitution. ${ }^{103}$ In Quin, Justice Brennan pointed to the separation of powers doctrine in justifying the Court's rejection of a substantive expectation:

[T] he court needs to remember that the judicature is but one of the three co-ordinate branches of government and that the authority of the judicature is not derived from a superior capacity to balance the interests of the community against the interests of an individual. The repository of administrative power must often balance the interests of the public at large and the interests of minority groups or individuals. The courts are not equipped to evaluate the policy considerations which properly bear on such decisions, nor is the adversary system ideally suited to the doing of administrative justice: interests which are not represented as well as interests which are represented must often be considered. ${ }^{104}$

\section{SOME OBSERVATIONS}

Taken together, these doctrines of constraint underscore the notion of deference. By limiting the scope of judicial review, they ensure that administrative institutions can carry out legislated functions, acting as a surrogate for parliamentary expression. That is, they ensure that democratic choice will only be subject to minimum limitations. In international investment treaty law, tribunals replace the judiciary in this equation. Tribunals, without constitutional ties or a predisposition to domestic principles of judicial review, have failed to recognize the importance of principle of deference. This failure is most evident in the expressed view of a number of tribunals that the doctrine of legitimate expectations protects substantive expectations, creating a channel for tribunals to review parliamentary intent.

\section{SUBSTANTIVE LEGITIMATE EXPECTATIONS IN INVESTMENT TREATY LAW}

The emergence of substantive expectations in select domestic jurisdictions has acted as a catalyst for its introduction into investment treaty arbitration. ${ }^{105}$ Substantive expectations have now become an entrenched part in investment jurisprudence. This is partly due to the

In Lam, supra note 72 at para 32, the High Court rejected the notion of substantive expectations and ruled that the jurisdiction vested in the High Court by section 75(v) of the Australian Constitution "does not exist for the purpose of enabling the judicial branch of government to impose upon the executive branch its ideas of good administration.” 
fact that awards that had initially mapped the scope of the doctrine to include substantive expectations were relied on by subsequent tribunals, creating a snowball effect.

The Tribunal in Técnicas Medioambientales Tecmed, SA v Mexico ${ }^{106}$ was the first to explicitly outline the scope of an investor's legitimate expectations under the investment treaty law regime. McLachlan calls the award " $\mathrm{t}]$ he most far-reaching exposition of the principle underlying the developing notion of legitimate expectations as applied to fair and equitable treatment." 107 The dispute in question concerned the replacement of a licence of indefinite term for the operation of a landfill site with a licence of limited term. In the award, the Tribunal outlined what it considered the framework of investor expectations:

\begin{abstract}
The Arbitral Tribunal considers that this provision of the Agreement, in light of the good faith principle established by international law, requires the Contracting parties to provide to international investments treatment that does not affect the basic expectations that were taken into account by the foreign investor to make the investment. The foreign investor expects the host State to act in a consistent manner, free from ambiguity and totally transparently in its relations with the foreign investor, so that it may know beforehand any and all rules and regulations that will govern its investments, as well as the goals of the relevant policies and administrative practices or directives, to be able to plan its investment and comply with such regulations. $^{108}$
\end{abstract}

This onerous standard requires that governments, whose power and rule are subject to changing social, economic, and political circumstances, behave in a consistent manner, free from ambiguity and with total transparency. This award has been subject to much criticism, ${ }^{109}$ yet has formed the basis of much of the arbitral jurisprudence that specifically deals with the legitimate expectations of the investor. ${ }^{110}$

(Award) (International Centre for Settlement of Investment Disputes (ICSID), Case No ARB (AF)/00/2, 29 May 2003), online: ICSID <http://icsid.worldbank.org> [Tecmed].

107 McLachlan, Shore \& Weiniger, supra note 2 at 235.

108 Tecmed, supra note 106 at para 154.

McLachlan, supra note 29 at 377 citing Zachary Douglas, "Nothing if Not Critical for Investment Treaty Arbitration: Occidental, Eureko and Methanex" (2006) 22:1 Arb Int'l 27 at 28 [emphasis in original]:

The Tecmed "standard" is actually not a standard at all; it is rather a description of perfect public regulation in a perfect world, to which all states should aspire but very few (if any) will ever attain.

But in the aftermath of the tribunal's correct finding of liability in Tecmed, the quoted obiter dictum in that award, unsupported by any authority, is now frequently cited by tribunals as the only and therefore definitive authority for the requirements of fair and equitable treatment.

Schill argues that a problem with relying on this case is the fact that its legal analysis is thin: "[G]iven the vagueness of fair and equitable treatment and the lack of guiding State practice, the 'interpretation' offered by the Tribunal in Tecmed effectively constitutes an act of delegated law-making that decided to apply a certain normative standard as part of fair and equitable treatment, rather than an interpretation based on deductive legal reasoning.” Schill, supra note 32 at 335.

110 CMS Gas Transmission Company v The Argentine Republic (Award) (ICSID, Case No ARB/01/8, 12 May 2005) at para 279, online: ICSID <http://icsid.worldbank.org> [CMS]; Azurix Corporation $v$ The Argentine Republic (Award) (ICSID, Case No ARB/01/12, 14 July 2006) at para 316, online: ICSID <http://icsid.worldbank.org> [Azurix]; Enron Corporation and Ponderosa Assets, LP v The Argentine Republic (Award) (ICSID, Case No ARB/01/3, 22 May 2007) at para 262, online: Amercian Society of International Law <http://www.asil.org/ilib/Enron.pdf> [Enron]; Occidental Exploration and Production Company $v$ The Republic of Ecuador (Award) (London Court of International Arbitration, Case No UN 3467, 1 July 2004) at para 185, online: University of Victoria <http://ita.law.uvic.ca/ documents/OxyEcuadorFinalAward-001.pdf $>$ [Occidental]. Schill notes that the Tecmed approach to fair and equitable treatment has "been adopted by several tribunals as if it were binding precedent for BITs between Chile and Malaysia, Ecuador and the United States, the Netherlands and Poland and others.” Supra note 32 at 333 . 
The emergence of a substantive legitimate expectation followed the Tecmed decision, as tribunals incorporated the transparency and "free from ambiguity" requirements of the Tecmed standard and incorporated them into what would become a "key element"111 of the fair and equitable treatment standard — the duty of host states to maintain the "stability of the legal and business framework." 112 Whether they have or have not met this duty is determinative of whether an investor's substantive expectations have been disappointed. Operation of this requirement can be described as such:

When investors acquire rights under domestic law, the fair and equitable treatment standard will protect legitimate expectations about the use and enjoyment of these rights. This requires a basic level of stability and predictability in the legal framework. Fundamental changes in the legal framework that eviscerate legitimately acquired rights are likely to violate fair and equitable treatment. ${ }^{113}$

The nature of these "fundamental changes" are at the heart of the issue. State regulatory action in the most traditional sense, such as the ability to introduce new legislation and change taxation or economic policy, are a practical part of governing in the public interest. Investment tribunals, however, have used the "stability and predictability" requirement to review such actions and ultimately find them in violation of the fair and equitable treatment standard. This is most clearly seen in cases where governments have made legislative changes.

In Occidental, one of the first tribunals to frame the Tecmed standard under the stability and predictability requirement, a US company operating in Ecuador had concluded a contract that included a provision that allowed the company to be reimbursed amounts of value-added tax (VAT) from purchases made for business related activities. A short time after, the Ecuadorian tax authorities revoked this practice and refused to accept Occidental's application for VAT refunds. The tax authorities took the position that the VAT reimbursement was already accounted for in the contract. Occidental filed a claim citing a breach of the fair and equitable treatment standard. The Tribunal held that "[t]he tax law was changed without providing any clarity about its meaning and extent" "114 and that "such requirements [of the fair and equitable treatment standard] were not met by Ecuador." 115 Essentially, the Tribunal held that the government's changes to the tax legislation (imputing legislation in general), which failed to meet the "free from ambiguity" component of Tecmed standard, ${ }^{116}$ undermined the stability and predictability of the business environment and thus precipitated state liability. This position was clearly problematic for Ecuador, as it is for most states, whose taxation policy is generally precluded from review by international tribunals.

Tribunals have also found that a series of legislative changes were found to upset the stability of the legal and business framework. In PSEG Global Inc and Konya Ilgin Elektrik treatment is the requirement of a 'stable framework for the investment,' which has been prescribed by a number of decisions."

Occidental, supra note 110 at para 183.

Newcombe \& Paradell, supra note 20 at 286.

Occidental, supra note 110 at para 184.

Ibid at para 186.

Ibid at para 185. 
Üretim ve Ticaret Ltd Şirketi v. Republic of Turkey, ${ }^{117}$ a US company signed a concession agreement with the Turkish government for the construction of coal-fired power plant in Turkey. After spending millions of dollars on negotiations and feasibility studies, PSEG found themselves in a negotiation deadlock. ${ }^{118}$ This was in part due to legislative changes and the passing of a law that removed the possibility of obtaining a guarantee for the project. PSEG commenced arbitral proceedings, claiming that, among other standards, Turkey's action amounted to a violation of fair and equitable treatment. The Tribunal, in finding a violation of fair and equitable treatment, held, "that the fair and equitable treatment obligation was seriously breached by what has been described above as the 'roller-coaster' effect of the continuing legislative changes." ${ }^{\text {"199 }}$ It concluded by noting: "Stability cannot exist in a situation where the law kept changing continuously and endlessly, as did its interpretation and implementation.",120

Investment tribunals have extended this strict reasoning to situations where legislative changes were undertaken as "emergency measure" situations where one would assume that states are accorded even greater deference. This was the case in a series of tribunal awards (three in total), all of which reviewed the regulatory decisions that Argentinean government took in response to the financial crises it suffered in the late 1990s to early 2000s. In each of the cases, all factually identical, three separate tribunals found that the Argentinean government had failed to maintain a stable and predictable legal and business framework. At issue in these cases was a tariff currency conversion provision, legislatively passed by the Government of Argentina in a bid to attract foreign investment. The legislation allowed investors to calculate tariff costs in US dollars. Once the crisis hit, Argentina adopted emergency measures including the elimination of the right to calculate tariffs in US dollars and pegged the tariff calculations to pesos at a rate of one dollar to one peso. This "correction," coupled with the devaluation of the peso, facilitated massive profit loss for the companies forced to use the new calculation scheme.

In $C M S$, the first of three cases against Argentina, the claimants argued that terminating the practice of allowing CMS to calculate tariff costs in US dollars was inconsistent with their expectation that Argentina would "maintain a stable framework for investments." ${ }^{121}$ The Tribunal found that Argentina was in violation of the fair and equitable treatment standard, as the emergency measures "did in fact entirely transform and alter the legal and business environment under which the investment was decided and made."122 Similarly, in Enron, the claimant Enron commenced proceedings against Argentina, claiming that the "emergency laws" were tantamount to the dismantling of the regulatory framework and thus were in violation of the fair and equitable treatment provision as found in the BIT. The Tribunal agreed with Enron's position and held: "The measures in question in this case have beyond any doubt substantially changed the legal and business framework under which the

(Award) (ICSID, Case No ARB/02/5, 19 January 2007), online: ICSID <http://icsid.worldbank.org> [PSEG Global].

There was disagreement as to the corporate structure of the project.

PSEG Global, supra note 117 at para 250.

Ibid at para 254.

CMS, supra note 110 at para 274, citing the Treaty between the United States of America and the Argentine Republic Concerning the Reciprocal Encouragement and Protection of Investment, 14 November 1991, 31 ILM 124 (1992), art VIII. 
investment was decided and implemented.” ${ }^{123}$ In last case, LG\&E Energy Corp v Argentine Republic, the Tribunal reiterated the Tecmed standard and decided in congruence with the other tribunals:

[T]his Tribunal, having considered, as previously stated, the sources of international law, understands that the fair and equitable standard consists of the host State's consistent and transparent behavior, free of ambiguity that involves the obligation to grant and maintain a stable and predictable legal framework necessary to fulfill the justified expectations of the foreign investor. ${ }^{124}$

These cases were particularly alarming; the investment tribunals found violations of the fair and equitable treatment standard despite the fact that the regulatory actions were emergency measures. In fact, these tribunals ruled that the defence of necessity, a legal defence found at international law, was not applicable in considering a breach of the fair and equitable treatment standard ${ }^{125}$ and that the "investor's right to compensation was not extinguished or moderated by circumstances of public emergency." ${ }^{126}$ Under this scenario a state seems perpetually doomed, as the maintenance of the duty to maintain a stable and predictable legal and business framework is a practical impossibility.

The above-mentioned cases have one thing in common: tribunals are using the requirement that a host state maintain a predictable and stable business framework, as a foundation for reviewing the regulatory decision of governments. This requirement, as expressed in Tecmed and followed in a number of other awards, is onerous and demands that host states operate without any inconsistency or ambiguity. Such a hardline position is problematic for a number of reasons: it is impossible for states to be clear and consistent in every circumstance, adopting such a strict standard could have adverse effects on states whose regulatory regime affords officials broad discretionary powers, and it could mean that states would be held liable for changing their legal framework to meet the clarity requirement. ${ }^{127}$ This liability, as we have seen, can extend to a state's regulatory response to a national emergency. These results are unsatisfactory and are precisely the reason why the doctrine of legitimate expectations must reflect the commonalities of the domestic approaches. Moreover, the injury extends beyond the compensatory damages that states are left to pay out to successful claimants, as onerous application of the "predictable and stable" requirement has the potential to "freeze" the regulatory sphere in hopes of avoiding further liability. As will be discussed in Part VI, this requirement, as with a substantive legitimate expectation in general, creates an avenue for investors, through tribunals, to place a stronghold on government regulatory action.

\section{TOWARDS A NEW DEFINITION}

The absence of the domestic doctrines of restraint in investment treaty jurisprudence creates a multitude of problems for host states whose approach to the doctrine of legitimate

123 Enron, supra note 110 at para 264.

124 (Decision on Liability) (ICSID, Case No ARB/02/1, 3 October 2006) at para 131, online: ICSID

$<$ http://icsid.worldbank.org>.

CMS, supra note 110 at paras 317-33.

Van Harten, supra note 23 at 3.

See Susan D Franck, “Occidental Exploration \& Production Company v. Republic of Ecuador” (2005) 99 AJIL 675 at 679. 
expectations only includes procedural protections. The failure of investment tribunals to recognize these doctrines signals an interpretive error, but also reflects the fact that tribunals are only bound by treaty and general international law, not the confines of a constitution or principles of judicial review. Instead, the balance of power that is accorded to the legislative branch in the domestic context is shifted away from the state towards the arbitrator (and arguably the investor). As will be evaluated in this section, host states and investors, and the investment treaty regime in general, would benefit from a "re-mapping" of the doctrine of legitimate expectations in congruence with its “common core content." Not only would this allow for an accurate depiction of a general principle of law to be drawn, but it would create an investment climate where both states and investors would benefit from the resulting predictability and stability.

\section{A. Legitimate EXPectations: The PredicAment}

Up to now, no tribunal has satisfactorily defined the scope of the doctrine in a way that reflects its “common core content.” Instead, tribunals have hand picked domestic approaches from select jurisdictions to justify their inclusion of a substantive expectation. This approach is most notable in the requirement placed on host states to maintain a "stable legal and business environment." The onerous form this requirement has taken "in some awards, [notably Tecmed] is staggering and could not have been agreed to by the states concluding the treaties." 128 More troublesome, many of the cases which have had an opportunity to evaluate the doctrine in depth have instead replicated the standards set out in these awards. ${ }^{129}$

The failure to accurately construe a general principle of law for legitimate expectations, as we have seen, produces a definitional scope that lacks legal justification. It also increases the likelihood of states disengaging from the investment treaty system. Anthea Roberts describes this predicament:

\footnotetext{
As investment treaties create broad standards rather than specific rules, they must be interpreted before they can be applied. Investor-state tribunals have accordingly played a critical role in interpreting, hence developing, investment treaty law. Yet their jurisprudence frequently resembles a house of cards built largely by reference to other tribunal awards and academic opinions, with little consideration of the views and practices of states in general or the treaty parties in particular. This disconnect alienates treaty parties from the interpretive process, which increases prospects for dissonance between states and tribunals about interpretation and adds fuel to the growing fire about the legitimacy of investment treaty arbitration. ${ }^{130}$
}

Overcoming this dissonance is of short-term importance for two reasons: (1) in the immediate sense, to create an environment of stability and predictability for states as well as investors; and (2) to prevent regulatory chill. The long-term concerns of the legitimacy of the investment treaty regime, which has been discussed, should also be a driving force behind these reforms. 
First, when the content of a treatment standard such as the doctrine of legitimate expectations is interpreted in a way that has broad consensus, administrative bodies can navigate their discretion without fear of violating investors' rights, or worse, without creating the above-mentioned crisis of legitimacy/sovereignty. ${ }^{131}$ Conversely, when a general principle of law does not reflect the legal aspects that are common among states, it fails "to grasp common features those legal systems establish for the exercise of public power" 132 and creates an atmosphere where host states are uncertain whether liability can arise from their regulatory functions. The principles of judicial review are well developed in domestic law for a reason. They are central to the balancing of power dynamics in complex systems of governance. As was noted in Quin, the judiciaries, let alone arbitral tribunals, are not in a better position to judge policy decisions that weigh individual rights against the greater public interest. ${ }^{133}$

Second, tribunal awards can have a chilling effect in a state's regulatory environment. Regulatory chill refers to situations where, due to impending investment claims and the possibility of having to pay huge sums of damages, states re-evaluate their policy positions to avoid the potential payout. It can also have an effect on how host states conduct themselves in investment matters as they "will be much less willing to establish good practices, publish guidelines, and give informal advice lest this conduct be turned against them." "134 As Schønberg notes, "[t]he extent of the chilling effect also depends upon the nature of the principle of legitimate expectations which is adopted." ${ }^{135}$ A tribunal that adopts an approach to the doctrine of legitimate expectations that is unfamiliar to the host state (as would be the case when a tribunal recognizes substantive legitimate expectations when the host state only recognizes procedural legitimate expectations) will increase the likelihood of regulatory chill occurring.

\section{B. What IS THE CoMmon CORE CONTENT?}

The comparative analysis undertaken in Part III, above, illustrates that there is no consistent doctrinal interpretation of legitimate expectations. Some states consider the doctrine to protect procedural protections only; others agree that this protection extends to substantive expectations. Within that distinction, there is a plethora of applicatory differences that can be distinguished. So what, then, could be considered the "common core content" of the domestic interpretation of the doctrine which would accurately reflect a general principle of law?

By surveying domestic approaches to the doctrine of legitimate expectations, it becomes apparent that the recognition of procedural legitimate expectations is present in almost all jurisdictions. Put another way, the doctrine of legitimate expectations provides procedural protections both in jurisdictions that have recognized substantive expectations, such as in Germany and the EC, and in jurisdictions where a movement towards substantive

Van Harten argues: "Most important are the implications for domestic systems of democratic choice as represented in domestic law, for example, by the principle of legislative supremacy.” Supra note 23 at 66. 
expectations has been rejected, such as in Canada and Australia. Schønberg, who has written extensively on the application of legitimate expectations in the European context, even concludes that English, French, and EC law all have similar sources of procedural protection. ${ }^{136}$ This commonality is in large part due to the fact that there is an acknowledgment on all sides that procedural safeguards are essential in protecting individuals from rights violations. ${ }^{137}$

There also seems to be an emerging agreement among the limited number of commentators who have taken a position on this issue that the doctrine's "core content" reflects its procedural roots. Giacinto della Cananea argues that "although standards differ from one national legal order to another, there exists common ground at the level of procedural requirements." ${ }^{138}$ McLachlin agrees and concludes that "[t]he standard is concerned with due process in decision-making, and not with substantive outcomes. It requires the application of fundamental rule-of-law values in decision-making: predictability; accessibility; impartiality; and natural justice, as contrasted with arbitrary action. ${ }^{139}$ Sornarajah comments on the doctrine as a general principle of law and concludes that "[i]t is an error to state that there is a general principle of law that violations of legitimate expectations give rise to substantive remedies." 140 His conclusion is based on the fact the substantive expectation approach is rarely used, mostly due to the fact that to do so would be impractical for governance reasons. ${ }^{141}$ Certainly this is the reason that many jurisdictions employ the doctrines of restraint — another key area that tribunals must explore when remapping their definition.

\section{IMPORTATION OF DOMESTIC DOCTRINES OF RESTRAINT}

In order to ensure stability and predictability in the investment treaty system, tribunals must acknowledge and import the notion of deference as reflected in the domestic doctrines of restraint into investment treaty jurisprudence as it relates to legitimate expectations. ${ }^{142}$ That is, in determining the applicable reaches and constraints the doctrine of legitimate expectations has over parties to an investment claim, arbitrators must "bear in mind the wellestablished limits in domestic law on the adjudication of regulatory disputes and on damages

Ibid at 34.

Giacinto della Cananea, "Equivalent Standards under Domestic Administrative Law: A Comparative Perspective” in Federico Ortino et al, eds, Investment Treaty Law: Current Issues II, Nationality and Investment Treaty Claims, Fair and Equitable Treatment in Investment Treaty Law (London: British Institute of International and Comparative Law, 2007) 149 at 159.

Ibid at 165.

McLachlan, supra note 29 at 400.

Sornarajah, Foreign Investment, supra note 35 at 355.

Sornarajah, ibid, states: "The principle has rarely been used as a substantive principle because of practical difficulties. Governments make assurances as to policies on taxation, agriculture and other areas. Administration would become difficult if, at each change of policy to suit new circumstances, the state has to pay damages to affected parties.”

This is not to suggest that tribunals import the doctrines of restraint as they are found in common law countries, but that they import the idea of deference, which underscores these principles. The doctrine of legitimate expectations is only recognized in a limited number of jurisdictions and thus there is no support for the argument that these doctrines of restraint, as found in common law jurisdictions, represent a general principle of law that can be applied to the doctrine of legitimate expectations. Instead, it is argued that these doctrines are useful for tribunals in that they generally delineate what regulatory actions deserve deference. 
as a public law remedy." 143 The often cited dissent of Professor Thomas Wälde in Thunderbird is illustrative of this point:

\begin{abstract}
The principle of legitimate expectation is also recognised in several developed systems of administrative law. The common principles of the principal administrative law systems are in my view an important point of reference for the interpretation of investment treaties to the extent investment treaty jurisprudence is not as yet firmly established.... The consulted authorities are indicative of contemporary state practice and the minimum standards of comparative national and international law. The "fair and equitable standard" [cannot] be derived from subjective personal or cultural sentiments; it must be anchored in objective rules and principles reflecting, in an authoritative and universal or at least widespread way, the contemporary attitude of modern national and international economic law. ${ }^{144}$
\end{abstract}

The principles of constraint are especially relevant for investment treaty tribunals. Under investment treaty arbitration, "legislative decisions are reviewable just like any other state measure and, as such, arbitrators may decide that legislation is unlawful and award damages as a remedy in public law.”" ${ }^{145}$ This can occur frequently as investment treaty tribunals are often asked to review changes to environmental, healthcare, or financial markets policies. In common law jurisdictions, this problem has been tempered by the principles of legislative supremacy, ${ }^{146}$ the doctrine against fettering, the ultra vires principle, or the separation of powers doctrine. Gus Van Harten recognizes that the same governance issues that are addressed in domestic law are found in investment treaty law and argues that it only makes sense we look to those jurisdictions for answers. He states:

\begin{abstract}
The idea of awarding damages to individuals for sovereign wrongs raises thorny issues about the scope and purpose of state liability and the appropriate role of government. Should damages be awarded to compensate individuals, or to deter inappropriate state conduct? Should liability be limited by requirements of malice or fault on the part of the state, or in light of the need to maintain flexibility and predictability in government? Should legislative or judicial acts be exempt from liability? These important questions have previously been resolved almost exclusively by domestic public law, as part of the reserved domain of domestic jurisdiction. With investment treaty arbitration, they are brought within the discretion of arbitrators. In turn, approaches to state liability that evolved in domestic law become more relevant to international adjudication. ${ }^{147}$
\end{abstract}

\title{
D. SOME OBSERVATIONS
}

Accurately depicting a general principle of law for the doctrine of legitimate expectations is essential if predictability and stability are the goals of the investment treaty regime. The only way to accomplish this task is by determining the "common core content" of the doctrine, reflecting a broad consensus and not a normative agenda. ${ }^{148}$ As is evident in state practice, the doctrine of legitimate expectations, at its common core, is about providing

Van Harten, supra note 23 at 150.

International Thunderbird Gaming Corp v. The United Mexican States (Separate Opinion) (NAFTA, 26 January 2006) at paras 28, 30 [footnote omitted], online: University of Victoria <http://ita.law. uvic.ca/documents/ThunderbirdSeparateOpinion.pdf $>$.

Van Harten, supra note 23 at 66 [footnote omitted].

Ibid at 67.

Ibid at 107 [footnotes omitted].

Brower and Schill identify one of the main criticisms against arbitrators, that arbitrators are likely to be biased towards investors, since appeasing investors will lead to their potential reappointment. Supra note 7 at $489-90$. 
procedural protections. Recognition of substantive legitimate expectations does not represent a shared experience and certainly clashes with the doctrines of restraint as found in some of the jurisdictions who have considered the doctrine in most depth.

\section{THE WAY FORWARD}

The realization of this jurisprudential reform can take several forms. In the simplest and most ideal form, a tribunal could correctly identify the "common core content" of the doctrine in an award and have subsequent tribunals adopt its reasoning (much like the Tecmed award). As argued, this can be accomplished through a comprehensive comparative analysis that considers such questions as "whether the host State must pro-actively foster the success of investments in its territory, when a State can change the pre-investment regulatory environment and what procedural formalities, if any, will be required to make such modifications without triggering an obligation to compensate the investor." 149 This modification will then set the trend and act as a catalyst in creating a coherent body of case law that accurately depicts legitimate expectations as a general principle of law.

However, the reality is that investment tribunals only owe an allegiance to the contracting parties and investors to a dispute. Even though it is arguable that tribunals owe a general duty to correctly interpret international law, as they use international legal standards to "resolve core matters of public law,"150 there is less impetus for tribunals to undertake an exhaustive comparative examination of the doctrine of legitimate expectations absent a request of the parties.

One important avenue through which states can have a direct hand in interpretation of the doctrine is through the negotiation/re-negotiation of their BITs. In the case of the North American Free Trade Agreement Between the Government of Canada, the Government of the United Mexican States and the Government of the United States of America, ${ }^{151}$ the state parties have the option of releasing binding interpretive statements which give tribunals direction. A state-driven approach, although an emerging trend, is costly and time consuming and therefore not the most expedient remedy.

That being said, it is more realistic to expect the remapping of the doctrine of legitimate expectations to take place incrementally, on a case-by-case scenario. Two distinct solutions, which would provide the interpretive flexibility required to encourage this process, are a recognized margin of appreciation and a proportionality analysis. The development of either of these approaches in investment jurisprudence would give tribunals enough flexibility to consider the unique regulatory obligations of host states. In so doing, tribunals pay due regard to domestic approaches to the doctrine, including any relevant principles of judicial review. It is hoped that these awards would then form part of the discursive shift that brings about the reshaping of doctrine in investment treaty law. 


\section{A. State-Driven APProAches}

The past few years have seen a number of states either create or revise their model BITs. ${ }^{152}$ The impetus behind this movement is to create/change the model BITs to incorporate "innovative features aimed at rebalancing the agreements between the rights and obligations of investors and host countries, as well as between economic and other public policy objectives.”153 Creating or updating model BITs has the advantage of allowing states "to pronounce a country's position on the proper interpretation of particular provisions found in earlier treaties." 154 For instance, both the US and Canada have created new model BITs, both of which define the fair and equitable treatment standard as "nothing more than a reference to the 'customary principles' on the international minimum standard." 155 This was done in an effort to reign in some of the more expansive interpretations tribunals have come up with. Other countries have followed their lead. ${ }^{156}$ Moreover, and perhaps in an effort to avoid the interpretive failures brought on the vagueness of the fair and equitable treatment standard, some countries have left out reference to the fair and equitable standard in recent treaties. ${ }^{157}$ Another option for states creating or renegotiating model BITs is to incorporate formal mechanisms like binding interpretive statements, similar to that afforded to the NAFTA parties, which "put investors on clear notice about the nature of the interpretive powers retained by the treaty parties."

Though this certainly is the most authoritative way to address the problem of interpretation that this article addresses, the budgetary and time constraints cannot be overstated. First, as Roberts notes, "the transaction costs involved in renegotiating thousands of bilateral investment treaties may be prohibitive.”159 This is especially true for states from the developing world. Second, creating or renegotiating model BITs is a lengthy process. It is more difficult, in the interim, to address what state parties consider as interpretive failures. It is precisely for these reasons that emphasis must be placed on the tribunals themselves to correctly interpret treaty provisions.

United Nations (UN), World Investment Report 2010: Investing in a Low-Carbon Economy (Geneva: United Nations, 2010) at 85-86, online: UNCTAD <http://www.unctad.org/en/docs/wir2010_en.pdf>. UNCTAD reports that the following countries recently created new model BITs:

[T]he Russian Federation in 2001 with an amendment in 2002, France in 2006, and Colombia,

Mexico, Austria and Germany in 2008).... Others are currently in the process of developing a new model BIT (Argentina, the Bolivarian Republic of Venezuela, Ecuador, Morocco, the Plurinational

State of Bolivia, South Africa, Turkey, and the United States), and more are planning a review process (Thailand and India with model BITs dating from 2002 and 2003, respectively).

Also according to UNCTAD: "Following a relatively stable trend of nine to 15 renegotiated BITs per year since 2000, 19 BITs were renegotiated in 2009; almost one quarter of the BITs concluded in 2009 are renegotiated ones,” ibid at 86.

Ibid at 82 .

Ibid at 85

M Sornarajah, "The Fair and Equitable Standard of Treatment: Whose Fairness? Whose Equity?” in Ortino, supra note 137167 at 169 [Sornarajah, "Whose Fairness"].

"[N] $]$ wer treaties like the ASEAN Comprehensive Agreement on Investment (2009) refer to the standard in the context of customary law." Sonarajah, Foreign Investment, supra note 35 at 355.

"Thus, the investment provisions of the India-Singapore Comprehensive Economic Cooperation Agreement contain no reference to the standard. The treaties of India and China, two of the largest recipients of investment, avoid references to the standard." Sonarajah, "Whose Fairness," supra note 155 at 169 .

Roberts, supra note 2 at 216.

Ibid at 192. 


\section{B. MARgin OF APPRECIATION DOCTRINE}

The development of a margin of appreciation doctrine in investment treaty jurisprudence would allow tribunals to recognize the regulatory obligations of states and, as Dolzer states, "favor the state in case of doubt." ${ }^{160}$ This idea is largely based on the doctrines of constraint discussed above. ${ }^{161}$ Yuval Shany argues that a margin of appreciation doctrine has the same intent and effect as the domestic principles. She argues that

domestic and international courts are comprised of non-directly-elected individuals, their suitability to make important choices regarding social conditions within states is controversial. Arguably, such choices should be taken, whenever possible, by democratically elected officials, i.e., the government apparatus, through a process of public deliberation. ${ }^{162}$

Consequently, this doctrine would require tribunals to recognize the privileged position of the government apparatus and show deference accordingly. William Burke-White and Andreas von Staden argue that this approach is optimal, as it "shifts the nature and location of that balancing from a direct comparison of a national regulation and a state's interests on one side, with investor rights on the other, to a determination of the appropriate width of the margin for a particular type of rights or interests, and a residual consideration of the justification for interference with individual rights."163 Though theoretically sound, practically speaking this approach is less tenable than the proportionality approach because it reduces the amount of power investors have. Without the level of protection investors are accustomed to, they may be less willing to invest abroad. This would hurt host states and investors alike.

\section{Proportionality ANALYsis}

The development of a "proportionality analysis" in investment treaty law is another way for tribunals to provide a "balanced" assessment of the interests of host states against those of the investors bringing the claims. "Proportionality analysis is a method of legal interpretation and decision-making in situations of collisions or conflicts of different principles and legitimate public objectives." ${ }^{164}$ It has been used in a diversity of domestic/international contexts, including Canadian law (the Oakes test ${ }^{165}$ ), the Constitutional Court of South Africa, the European Court of Justice, the International Court of Justice, in World Trade Organization law, and by the European Convention on Human Rights. ${ }^{166}$ Although in its developmental infancy, use of the proportionality analysis is on the rise in investment treaty law. ${ }^{167} \mathrm{~A}$ small number of awards have sought to move away from the onerous standard laid out in Tecmed and instead have created a "balanced approach" that,

Supra note 30 at 970 [footnote omitted].

As discussed, at supra note 21.

Yuval Shany, “Toward a General Margin of Appreciation Doctrine in International Law?” (2005) 16:5 EJIL 907 at 920 [footnotes omitted].

William W Burke-White \& Andreas von Staden, "Private Litigation in a Public Law Sphere: The Standard of Review in Investor-State Arbitrations” (2010) 35:2 Yale J Int'l L 283 at 337 [footnote omitted].

Kingsbury \& Schill, supra note 8 at 30.

$R v$. Oakes, [1986] 1 SCR 103 [Oakes].

Kingsbury \& Schill, supra note 8 at 34-38.

Brower \& Schill, supra note 7 at 484. 
when approaching the "stable legal and business environment" requirement, weigh the obligations of states against the rights of the investor.

Proportionality analysis, however, is problematic in one sense. Whether it is utilized effectively is determined by "the ability of judges or arbitrators to balance among competing rights or interests and to convince both states and investors that they have struck the appropriate balance.”"168 This "balancing act” is subject to a variety of influences, including the biases of the tribunal panel and their approach to the legal issue. Burke-White and von Staden outline this challenge in the context of ICSID arbitrations:

\begin{abstract}
While our view is that the tribunal should accord preference to the continued existence of the state and the safety of individuals from public riots over investor property, that outcome is not necessarily a given and depends in large part on the preferences and predilections of arbitrators, many of whom in the ICSID context are themselves private litigators. ${ }^{169}$
\end{abstract}

\title{
D. DEFERENCE IN INVESTMENT TREATY JURISPRUDENCE
}

As noted, there has been a slow but growing inclusion of proportionality analysis in investment treaty jurisprudence. The seminal case for deference in investment treaty law is Saluka. The case concerns measures taken by the Czech government to assist (financially) three banks of which it was a majority shareholder. A fourth bank, IPB, was a private bank for which Saluka held a substantial equity share. Because it was privately owned, IPB was not given the same financial help as the other banks. Instead of providing financial support, and much to the dismay of Saluka, the Czech government put the private bank into forced administration. The Tribunal was asked to decide whether the Czech government's actions amounted to expropriation and violations of the fair and equitable treatment (FET) provisions as per the Czech Republic-Netherlands BIT.

The Tribunal, which dismissed the expropriation claim and recognized that the FET provision had been violated, called for a balanced approach when determining whether a FET violation has occurred. First, the Tribunal admonished the position taken in Tecmed, warning that taking the idea "too literally, they would impose on host States' obligations which would be inappropriate and unrealistic." ${ }^{170}$ Second, the Tribunal outlined the required balancing act:

\footnotetext{
No investor may reasonably expect that the circumstances prevailing at the time the investment is made remain totally unchanged. In order to determine whether frustration of the foreign investor's expectations was justified and reasonable, the host State's legitimate right subsequently to regulate domestic matters in the public interest must be taken into consideration as well. ${ }^{171}$
}

This interpretation given by the Tribunal has important implications. It requires that tribunals recognize that states be given regulatory flexibility. This will allow states "to respond to 
changing circumstances in the public interest." ${ }^{, 172}$ Also, by recognizing this flexibility, investors' expectations will not "be equated with a vested property right.".173

Tribunals have also started to take the position that the duty to provide investors with stability and predictability is not an absolute guarantee ${ }^{174}$ since changes to a state's legal framework are an inevitable and necessary element of governance. In ParkeringsCompagniet AS $v$ Republic of Lithuania ${ }^{175}$ for example, the claimant entered into a contractual relationship with a Lithuanian municipal government for the right to operate parking lots for a period of 13 years. This contract was short-lived, however, as the Lithuanian Parliament amended laws which directly affected Parkerings' profit levels. Soon after, the municipality terminated the contract. Parkerings filed a claim citing breaches of the fair and equitable treatment standard found in the Lithuania-Norway BIT. The Tribunal found no violation of the FET standard, but took the time to speak about the qualified nature of an investor's legitimate expectations:

\footnotetext{
It is each State's undeniable right and privilege to exercise its sovereign legislative power. A State has the right to enact, modify or cancel a law at its own discretion. Save for the existence of an agreement, in the form of a stabilisation clause or otherwise, there is nothing objectionable about the amendment brought to the regulatory framework existing at the time an investor made its investment. As a matter of fact, any businessman or investor knows that laws will evolve over time. What is prohibited however is for a State to act unfairly, unreasonably or inequitably in the exercise of its legislative power. ${ }^{176}$
}

More recently, the Tribunal in EDF (Services) Ltd v Romania17 adopted the "balanced approach" taken in Saluka and Parkerings. In this case, the claimant, EDF, entered into agreements with two state-owned companies to provide duty-free and retail offerings in Romanian airports and on-board flights. The state-owned companies refused to renew the contracts for commercial reasons. EDF then filed a claim, citing alleged violations of the expropriation and fair and equitable provisions of the BIT. The Tribunal dismissed the claim, finding that the stability and predictability of the legal and business framework benchmark that had been used by tribunals in the past, "may not be correct if stated in an overly-broad and unqualified formulation." ${ }^{178}$ If the standard is incorrectly applied, the Tribunal noted, it could lead to a "virtual freezing of the legal regulation of economic activities, in contrast with the State's normal regulatory power and the evolutionary character of economic life."179 The Tribunal went on to say:

Legitimate expectations cannot be solely the subjective expectations of the investor. They must be examined as the expectations at the time the investment is made, as they may be deduced from all the circumstances

McLachlan, Shore \& Weiniger, supra note 2 at 239.

Ibid.

Kinnear, supra note 24 at 288.

(Award) (ICSID, Case No ARB/05/8, 11 September 2007), online ICSID <http://icsid.worldbank.org> [Parkerings].

Ibid at para 332.

(Award) (ICSID, Case No ARB/05/13, 8 October 2009), online: ICSID <http://icsid.worldbank.org> $[E D F]$.

Ibid at para 217.

Ibid. 
of the case, due regard being paid to the host State's power to regulate its economic life in the public interest. $^{180}$

\section{E. Due Diligence}

Tribunals are also starting to give regard to the due diligence that investors must undertake as a part of their investment. This requires investors to anticipate changes that seem reasonable in light of the circumstances. In Parkerings, the Tribunal noted that an investor's right to a stable and predictable investment environment is considered along with whether they properly assessed the related risks:

In principle, an investor has a right to a certain stability and predictability of the legal environment of the investment. The investor will have a right of protection of its legitimate expectations provided it exercised due diligence and that its legitimate expectations were reasonable in light of the circumstances. Consequently, an investor must anticipate that the circumstances could change, and thus structure its investment in order to adapt it to the potential changes of legal environment. ${ }^{181}$

An even stronger warning came from the Tribunal in MTD Equity Sdn Bhd and MTD Chile $S A v$ Republic of Chile, which ruled that a company that bases its risks against a number of assumptions, but does not protect itself in case those assumptions do not materialize, cannot be protected by a claim of legitimate expectation. ${ }^{182}$ The Tribunal stated: "The BITs are not an insurance against business risk and the Tribunal considers that the Claimants should bear the consequences of their own actions as experienced businessmen.”183

These cases provide the basis for the proportionality analysis to become an entrenched principle in investment treaty jurisprudence. Recognition of this "balanced approach" is not yet widespread, but Brower and Schill note that there is increasing recognition that states "are not required to compensate foreign investors for the effects of bona fide, general regulations that further a legitimate purpose in a nondiscriminatory and proportionate way." 184 This development is especially germane in dealing with vague treatment standards, such as fair and equitable treatment. Kingsbury and Schill note that

when deployed by sophisticated courts and tribunals in national and international jurisprudence to deal with open-ended concepts and difficult balancing, it [proportionality analysis] has proven to be methodologically workable and more coherent and generalizable than the kinds of reasoning applied by many tribunals to "fair and equitable treatment" clauses or the concept of indirect expropriation. The diversity of existing uses of proportionality analysis means that it is possible to undertake wide-ranging and instructive comparative law research and analysis as to what is considered as proportional in various national legal systems and transnational or international tribunals. ${ }^{185}$

$180 \quad$ Ibid at para 219.

181 Supra note 176 at para 333.

(Award) (ICSID, Case No ARB/01/7, 25 May 2004) at para 178, online: University of Victoria $<$ http://ita.law.uvic.ca/documents/MTD-Award.pdf $>$.

183 Ibid [footnote omitted].

$184 \quad$ Supra note 7 at 484

$185 \quad$ Supra note 8 at 31. 
The proportionality analysis, as a comparative tool, is particularly helpful for identifying the correct interpretation of legitimate expectations as a general principle of law. It will encourage tribunals to consider domestic interpretations in their reasoning and consequently contribute to a reworking of the doctrine of legitimate expectations in investment treaty jurisprudence.

\section{CONCLUSION}

The need to redefine the scope of the doctrine of legitimate expectations in investment treaty law is apparent. This article has taken the position that the first step in this reform process is the acknowledgment that the current approach to the doctrine in investment treaty jurisprudence as a general principle of law is in fact a misstatement of law. It betrays the requirement that the principle must be based on ideas that have broad consensus or reflect the "common core content" of domestic interpretations. A correct approach to the doctrine in investment treaty law then must be anchored in domestic counterparts.

An examination of the domestic sources of the doctrine of legitimate expectations unveils the variance of doctrinal approaches that exist. Among these differences, and at the forefront of the controversy assessed in this paper, there is split between jurisdictions that recognize both procedural and substantive expectations and those that only recognize procedural expectations. Investment tribunals have adopted the former approach by recognizing it as a general principle of law, despite the fact that it runs afoul of the domestic interpretations of the doctrine in a number of jurisdictions. Replication of this position by a number of tribunals in a number of awards has entrenched this approach.

Furthermore, in failing to correctly state a general principle of law by recognizing substantive expectations, investment tribunals have ignored a strong chorus of doctrines of constraint found in domestic law — such as the doctrine against fettering, legislative supremacy, the ultra vires principle, and the separation of powers doctrine. The notion of deference that underscores these doctrines would be helpful in providing instruction to tribunals to limit their review power, thus safeguarding the discretion of elected individuals from the purview of the courts, and thus protecting legislative intent. Without this notion of deference, tribunals have full review powers over the decisions of the domestic legislatures and administrative bodies without giving due regard to the unique position of either of these groups. Due to the nature of investment claims, this task is undertaken regularly ${ }^{186}$ Allowing this type of review certainly conflicts with the intent of many contracting parties whose domestic limits on judicial review reflect a concern that legislative decisions should not be reviewable outside of parameters set up by the legislature.

An area where this movement has been most troublesome is in the introduction of the requirement that host states maintain a predictable and stable legal business framework. In some awards, this requirement has been expressed in such a way that it has the effect of requiring that the host state freeze all regulatory activity. Not only is this a practical impossibility and completely counterproductive to any notion of working in the public's 
interest, but it creates a situation where a host state will be liable for disappointing an investor's legitimate expectations in almost every case.

The answers to these governance issues are, in a sense, simple. As noted, they already exist in domestic law. It is a duty to correctly identify a general principle of law that falls squarely on the shoulders of investment tribunals. A tribunal must engage this complex comparative challenge and "be sure that the standards for judicial or administrative decisionmaking which it exacts from municipal courts and administrators are general principles of law common to civilized nations, and not rules of law specific only to some national legal systems, but rejected by others." 187 This includes giving due consideration to the notion of deference as found in different domestic jurisdictions, including the doctrines of constraint found in the common law.

Investment treaty jurisprudence has made incremental steps towards this realization. There are a number of awards that accept that an interpretive balancing act must occur, weighing a state's regulatory obligations against an investor's rights. Building upon this momentum is critical for the development of an approach to the doctrine of legitimate expectations marked by deference. Ideally, the problem could be overcome if a single tribunal correctly identified legitimate expectations as a general principle of law, setting the standard which would then be replicated by other tribunals (much like Tecmed). What is more realistic, however, is for investment tribunals to build on the development of the balancing tests that have recently been introduced in a number of awards. Though this body of law is small, it could materialize as either a margin of appreciation doctrine or proportionality analysis principle in investment treaty jurisprudence. These legal devices would not solve the interpretive problem on their own, but they would provide arbitrators with an analytical framework to consider the domestic application of doctrine as well as the unique obligations of host states. These considerations are essential for the correct rewriting of the doctrinal approach to legitimate expectations in investment treaty law. 